\title{
Stalin, the Western Allies and Soviet policy towards the Yugoslav partisan movement 1941-1944
}

Soviet policy towards the Yugoslav partisans has rarely been explored as a subject in its own right, and almost never in terms of its development across the entire period between 1941 and $1944 .{ }^{1}$ It has been often used, rather, as a litmus test to shed light on related and broader topics.

Yugoslav historiography has been traditionally concerned to emphasise the autonomy of Tito's revolution, and consequently to play down support received from Moscow. According to this narrative, Stalin was determined to sacrifice revolutionary ambition on the part of the European communist parties on the altar of Soviet interests. Tito, by contrast, aimed to turn the war of liberation in Yugoslavia into a struggle to establish a new socialist state or, looking at the issue from a different angle, to pursue the interests of his country even if they did not fit with those of the Soviet Union. To support its claims, this historiography focused mainly on the 1941-1943 period, when the contrast between Stalin and Tito seemed most obviously apparent. Lacking appropriate Soviet records, this interpretation, which seemed vindicated by the 1948 split, also set the tone for many of the Western accounts which followed. ${ }^{2}$

Due to the disbandment of the Comintern in 1943, historians of the international communist movement with access to Russian documents also paid less attention to 1943-44 which, as far as Yugoslavia is concerned, remained in a sort of historiographical limbo between the Second World War and the Cold War. ${ }^{3}$ Those accounts that, by contrast, took a

\footnotetext{
${ }^{1}$ The only relevant exception in English is the unpublished P. Jukic, Uncommon Cause: the Soviet Union and the Rise of Tito's Yugoslavia, 1941-1945 (A Dissertation Presented to the Graduate School of Yale University 1997). Russian historiography paid comparatively more attention to the topic both through research contributions and collections of documents. See for example A.B. Edemskii, 'Moskva i Antifashistskoe Dvizhenie I. Broz Tito (Ianvar' - Nachalo Oktiabria 1944 g.)', in Oslobodjenje Beograda 1944 Godine. Zbornik Radova (Belgrade 2010), 95-129, A.M. Sergienko, Okazanie Sovetskim Soiuzom Voenno-Tekhnicheskoi i Kadrovoi Pomoshchi lugoslavii v Gody Vtoroi Mirovoi Voiny (Belgorod 2007), Russkii Arkhiv: Velikaia Otechestvennaia. Krasnaia Armiia v Stranakh Tsentral'noi, Severnoi Evropy. Dokumenty i Materialy. 1944-1945 (Moscow 2000) and Otnosheniia Rossii (SSSR) s lugoslaviei 1941-1945 gg. Dokumenty i Materialy (Moscow 1998).

${ }^{2}$ Among the most influential works conveying this view which have been translated are V. Dedijer, Tito Speaks: his Self Portrait and Struggle with Stalin (London 1953), M. Djilas, Conversations with Stalin (New York 1962) and M. Djilas, Wartime (New York, NY; London 1977). This approach is largely reflected in the most important collection of documents on the topic published in English, S. Clissold (ed.) Yugoslavia and the Soviet Union, 19391973: a Documentary Survey (London; New York, NY 1975).

${ }^{3}$ See F.I. Firsov, H. Klehr, and J.E. Haynes, Secret Cables of the Comintern, 1933-1943 (New Haven, CT 2014), M.M. Narinski and N.S. Lebedeva (eds.) Komintern i Vtoraia Mirovaia Voina, Chast' II, posle 22 liunia $1941 \mathrm{~g}$. (Moscow 1998) and, specifically on Yugoslavia, G. Swain, 'Tito and the Twilight of the Comintern', in T. Rees and
} 
long-term view, generally refer to Soviet policy towards Tito when dealing with the immediate June 1941 period, while for 1944 more emphasis is given to the directives issued to the French and the Communist parties, or to the events surrounding the outbreak of the Greek civil war. ${ }^{4}$

The question of Soviet policy has been recently re-addressed from the point of view of Tito's biography. In this context, more coverage has been given to events post-Teheran, stressing that Moscow's readiness to support Tito increased significantly once Stalin realised that this did not put him on a collision course with the British. ${ }^{5}$ But this focus upon Tito means that the extent of Soviet involvement has been largely neglected, as also internal debate within the Soviet camp, which shaped the formulation of Soviet policy during the entire course of the war.

This article follows the development of Soviet policy towards the communist partisan movement from the invasion of Yugoslavia in 1941 to the liberation of the country at the end of 1944. In doing so, it aims to address this topic for the first time through the lens of the Soviet decision making process, following its development across the entire duration of the war. During 1941-1942, the Comintern was indeed concerned by Tito's leftist stand, although this did not prevent Moscow recognizing his role as one of the key players in the region. Over the course of the war, the strict popular front strategy imposed on Tito in 1941 was progressively abandoned as a response to shifts in British policy and, in 1944, Moscow gave full support to the partisans' take-over of the country. The Soviet attitude towards Tito was also appreciably adapted as he changed from secretary of one of the parties subordinated to the Comintern into the leader of a new communist state in the making. The development of the Soviet policy, however, was not linear. On the contrary, it took shape in the context of many uncertainties and steps back caused by a lack of understanding of the British position, the attempt to deceive the Western Allies about the extent of relations with Tito, and also by the emergence of different perspectives amongst the Soviet Minister of Foreign Affairs, the Comintern and the Soviet military. The Soviets were largely successful in their attempt to

A. Thorpe (eds.) International Communism and the Communist International, 1919-43 (Manchester; New York, NY 1998), 205-21.

${ }^{4}$ For example S. Pons, The Global Revolution: a History of International Communism, 1917-1991 (Oxford 2014), 102-43.

${ }^{5}$ G. Swain, Tito: a Biography (London; New York 2011), 57-82 and J. Pirjevec, Tito e i suoi Compagni (Torino 2015), 142-55. 
support Tito whilst avoiding repercussions for the Great Alliance, although in the long term their achievements backfired.

The fire of resistance swept through Yugoslavia after the country was invaded by the Germans in April 1941. Repression at the hands of the nominally independent State of Croatia established by the Germans caused the first spontaneous insurrection of the Serbs, who acted largely in self-defence and with little coordination between disparate groups of rebels. In Serbia, by contrast, the resistance found a nucleus of organization developing around Dragoljub Mihailović and a group of Serbian officers who refused to accept the surrender. The British, who at that point were short of good news, hailed Mihailović as the hero of the European resistance and inflated his accomplishments 'to legendary proportions' .

In Yugoslavia, as everywhere across Europe, the communists joined the resistance only after the German invasion of June 1941. Stalin's long-term vision remained fixed on the expected showdown between socialist and capitalist forces that was at the root of the Marxist worldview, but the Comintern's policy was reoriented, reverting to the popular front tactics of the Thirties. In the wartime context, this meant that communist groups were mobilized to organize mass resistance movements against the Nazis, putting aside revolutionary slogans and collaborating with other opposition movements. ${ }^{7}$

As instructed by Moscow, after June 1941 Tito mobilized the Yugoslav communist party for an all-out war against the occupiers. ${ }^{8}$ But he also made it clear that he considered the struggle against the occupiers as a struggle for the triumph of Socialism. In mid-August he claimed that the Chetniks were fighting against the Partisans in cooperation with the

\footnotetext{
${ }^{6}$ S. Pavlowitch, Hitler's New Disorder: the Second World War in Yugoslavia (New York, NY 2008), 64 and S. Trew, Britain, Mihailovic and the Chetniks, 1941-42 (New York 1998), 36-38. Accounts of the Chetnik movement during the war available in English include L. Karchmar, Draža Mihailović and the Rise of the Četnik Movement, 19411942 (New York, NY; London 1987), M. Milazzo, The Chetnik Movement and the Yugoslav Resistance (Baltimore 1975), J. Tomasevich, The Chetniks (Stanford, CA 1975). The development of the Chetnik-Partisan conflict in Bosnia is covered by M.A. Hoare, Genocide and Resistance in Hitler's Bosnia: the Partisans and the Chetniks, 1941-1943 (Oxford; New York, NY 2006).

${ }^{7}$ On Comintern's policy after June 1941 Pons, The Global Revolution, 102-43, Firsov, Klehr, and Haynes, Secret Cables of the Comintern, 184-237, E. Mark, Revolution by Degrees: Stalin's National-Front Strategy for Europe, 1941-1947 (Washington, DC 2001) and Narinski and Lebedeva (eds.) Komintern i Vtoraia Mirovaia Voina, Chast' II, posle 22 liunia $1941 \mathrm{~g}$.

${ }^{8}$ Accounts of the Partisan movement in Yugoslavia tend to coincide with bibliographies of Tito. Among the more recent are Pirjevec, Tito e i suoi Compagni and Swain, Tito: a Biography. An updated account of the events in Yugoslavia during the war that pays special attention to the resistance movements is L.I. Gibianskii, 'Iugoslaviia v Period Vtoroi Mirovoi Voiny', in K.V. Nikiforov (ed) Iugoslaviia v XX Veke: Ocherki Politicheskoi Istorii (Moscow 2011), 305-522.
} 
Germans, ${ }^{9}$ and started urging Dimitrov to send weapons, pointing out that this would have 'huge political significance in the future'. ${ }^{10}$ Under the impression that the Red Army would quickly repel the German attack and advance through the Balkans, in September Tito established his headquarters in the city of Užice, in western Serbia. Here he set up a system of government under the strict control of the party, destroying tax and land records, introducing communist symbols and getting rid of real or imaginary "enemies of the people". At the beginning of November, the Partisans celebrated the anniversary of the October Revolution, and in 22 December, the day of Stalin's birthday, created the first "proletarian brigade". ${ }^{11}$ There was clearly no possible middle ground between the Chetniks and the communists, and at the beginning of November the country was engulfed in a civil war.

The British had little leverage over the situation. Their first attempt was thus to appeal to the Soviets, along with the Yugoslav government, in the hope that they might instruct the communist groups to subordinate to Mihailović.

At the end of 1941 the importance of Tito's movement was already clear to Dimitrov who, starting from September, pushed Molotov to send military supplies to Yugoslavia. ${ }^{12}$ The Comintern, which at that point had no connections with the Greek communist party, was also ready to acknowledge the key role that Tito might play in the entire region: the Albanian communist party was created in November under Yugoslav patronage, and a dispute with the Bulgarian party over the jurisdiction of Macedonia had already been resolved in favour of the Yugoslavs in August 1941. Contacts with the Italian communist party were also maintained through Yugoslavia. ${ }^{13}$ The situation was such, however, that any public stand in the TitoMihailović controversy was not considered advisable, and Moscow refused to commit itself with the British.

\footnotetext{
${ }^{9}$ Radiogramma General'nogo Secretaria KPlu I. Broz Tito Ispolnitel'nomu Komitetu Kominterna, 13.8.1941, in Otnoshenija Rossii (SSSR) s Jugoslaviej 1941-1945 gg. Dokumenty i materialy (Moscow 1998), 61.

${ }^{10}$ Radiogramma General'nogo Secretaria KPlu I Broz Tito Ispolnitel'nomu Komitetu Kominterna, [beginning of October 1941], in ibid., 70.

${ }^{11}$ Swain, Tito: a Biography, 38-40 and Pavlowitch, Hitler's New Disorder, 62.

12 Molotov, however, made it immediately clear that this was impossible because the needs were 'enormous' and Moscow would have to compensate 'for great losses' I. Banac (ed.) The Diary of Georgi Dimitrov, 1933-1949 (New Haven 2003), 8.9.1941, 193.

${ }^{13}$ B. Fischer, Albania at War, 1939-1945 (London 1999), 123-25, S. Palmer and R. King, Yugoslav Communism and the Macedonian Question (Hamden, CT 1971), 66-68 and Firsov, Klehr, and Haynes, Secret Cables of the Comintern, 201-2.
} 
On the one hand, the Soviets, who in September 1941 were contemplating sending a joint mission to Mihailović in collaboration with the British, ${ }^{14}$ were unsure about what was happening in the country. At the end of November the secretary of the Comintern, Dimitrov, asked Tito who was leading the Chetniks and which relation did they have with the Partisans. ${ }^{15}$ When Tito replied that they were just collaborators of the Germans, Moscow appeared unconvinced, suspecting that it was Tito who was not doing enough to achieve collaboration with other antifascist forces. A few months later Dimitrov was still insisting to Tito that it was hard to imagine that 'London and the Yugoslav government support the occupiers', as he claimed, and that the issues with the Chetniks 'must be a big misunderstanding' ${ }^{16}$

On the other hand, Moscow was clearly concerned that the leftist line adopted by Tito could damage its relations with both the Yugoslav government-in-exile and the British. Yet the possibility for the Soviets to appease the British by publicly pushing Tito towards a conciliatory course was limited, paradoxically, by Moscow's claim that the European communist parties were not the "long arm" of Moscow. ${ }^{17}$ When, at the beginning of December 1941, the British incorrectly notified them that the Chetniks had reached an agreement with the Partisans, the Soviets could not dispute this information, as to do so would imply that Moscow had a direct link with the Partisans or at least a link to independent sources inside the country. Moscow simply replied that it did not consider it advisable for the Soviet government to intervene in Yugoslav internal affairs, ${ }^{18}$ leaving the British to deal with the mess by themselves.

At the beginning of 1942, it was difficult to see how the Soviets could square the circle of three apparently incompatible goals: supporting Tito, avoiding the repercussions of this policy

\footnotetext{
${ }^{14}$ M. Deroc, British Special Operations Explored: Yugoslavia in Turmoil 1941-1943 and the British Response (New York, NY 1988), 194-204. See also M. Wheeler, 'Resistance from Abroad. Anglo-Soviet Efforst to Coordinate Yugoslav Resistance, 1941-42', in M. Seaman (ed.) Special Operations Executive: a New Instrument of War (London; New York 2006), 103-22.

${ }^{15}$ Firsov, Klehr, and Haynes, Secret Cables of the Comintern, 194-95.

${ }^{16}$ Dimitrov to Stalin and Others, 5 and 6 March 1942, doc. 45 in A. Dallin and F.I. Firsov, Dimitrov and Stalin, 1934-1943: Letters from the Soviet Archives (New Haven, CT; London 2000), 217.

${ }^{17}$ Back in April 1941 the Kremlin was already concerned that the formal affiliation of the communist parties with the Comintern might represent an obstacle both for the development of the parties and for Moscow's international relations, and started discussing the advisability of disbanding it. See Banac (ed.) The Diary of Georgi Dimitrov, 20.4.1941, 155-56 and Firsov, Klehr, and Haynes, Secret Cables of the Comintern, 238-39.

18 Pamiatnaia Zapiska NKID SSSR Posol'stvu v Velikobritanii v SSSR, 5.1.1942, in Otnoshenija Rossii (SSSR) s Jugoslaviej 1941-1945 gg., 90. The first draft of this document, which disputed British information, in Archive of Foreign Policy of the Russian Federation [AVP RF], f. 06, o. 4, p. 14, d. 141, I.4.
} 
for relations with the British when their help was more needed than ever, and sustaining the pretence that they had no control over the Yugoslav communist party. Tito, however, found a champion of his cause in Moscow in Dimitrov.

Dimitrov's first goal was to bring Tito in line with the Comintern's official position. On 5 March 1942 he accused Tito of giving grounds 'for the supporters of England and the Yugoslav government' to suspect that the partisan movement was 'acquiring a communist character and [was] aiming at the Sovietisation of Yugoslavia'. The secretary of the Comintern instructed him to 'seriously review [his] tactics and activities', and reminded him that 'the main task [was] to unite all the anti-Hitler elements in order to defeat the occupiers' ${ }^{19}$

Tito had good reasons to comply. The distance between him and the Soviet leadership was, at its roots, strategic, arising out of the eternal debate inside the international communist movement about the correct route to establish socialism. But negotiating the turbulent politics of the 1930s in the Moscow of the Great Purge had taught Tito the limits of his ability to manoeuvre, and especially that, to operate freely in internal politics, he had to pay lip service to the Soviet line in the international arena. ${ }^{20} \mathrm{He}$ also realized that his ultraradical line could alienate a vast part of the population. In April, the leadership of the party increased its campaign against 'sectarianism' and, under Soviet guidance, began a slow process of ideological reorganization under the guidance of Dimitrov. ${ }^{21}$

At the same time, Dimitrov started lobbying Molotov and Stalin in favour of the Yugoslav comrades, claiming that the British and the government-in-exile were obstructing the antiGerman effort of the resistance movement and urging the Soviet leadership to send weapons to the Partisans. ${ }^{22}$ The Soviet government, however, was uncertain as to how to proceed. As Andrey Vyshinskii, then Molotov's deputy, commented on 19 June 1942, it was difficult to keep the question of the Partisans separated from its context, and especially from the problem of relations with the government-in-exile. If Moscow were to address this issue, he wrote, 'it will be necessary to carry the matter through to the end'. 'Truthfully', he concluded,

\footnotetext{
${ }^{19}$ Dimitrov to Stalin and Others, 5 and 6 March 1942, doc. 45 in Dallin and Firsov, Dimitrov and Stalin, 19341943: Letters from the Soviet Archives, 217.

${ }^{20}$ G. Swain, 'Tito: the Formation of a Disloyal Bolshevik', International Journal of Social History, XXXIV (1989), 270-71 and Swain, 'Tito and the Twilight of the Comintern', 205-21.

${ }^{21}$ Swain, Tito: a Biography, 41-46 and Pirjevec, Tito e i suoi Compagni, 109-10.

22 Pis'mo G. Dimitrova I. Stalinu ob Otnoshenii Angliiskogo i lugoslavskogo Pravitel'stva k Partizanskomu Dvizheniiu v. Iugoslavii, 28.4.1942, in Narinski and Lebedeva (eds.) Komintern i Vtoraia Mirovaia Voina, Chast' II, posle 22 liunia 1941 g., 214-15 and Banac (ed.) The Diary of Georgi Dimitrov, 4.6.1942, 221.
} 
'I do not see such a possibility'. ${ }^{23}$ Molotov, moreover, was still not fully convinced by Tito's accusations against Mihailović, which seemed to him 'simplified and one-sided'. ${ }^{24}$

It took Dimitrov making an extra effort with Tito for Moscow to start considering a new position. At the beginning of June, while Soviet representatives in London were claiming that Moscow had no connections with Yugoslavia and bore no responsibility for the actions of the Comintern, ${ }^{25}$ Dimitrov delivered a lesson in popular-front tactics to Tito. The Partisans, he explained, were right to expose the activities of the Chetniks, but this should not be presented as an attack on the Yugoslav government, but rather as an appeal to it, 'emphasizing that the fighting Yugoslav patriots are entitled to expect that government's support'. Part of the Chetniks, he argued, should be won over, others neutralized and only 'the most malicious part of them' destroyed 'without mercy'. He believed that the campaign against the class enemy should be conducted in the name of unity, without giving the impression that it was party oriented. He therefore considered it expedient to organize some form of appeal 'by well-known Yugoslav public figures and politicians against collaborators and in favour of the Part[isan] people's liberation army', and possibly also to set up a 'national committee for aid for the Yugoslav people's war of liberation' with the participation of 'well-known patriotic Serb, Croat, Montenegrin, and Slovene public figures'. ${ }^{26}$ Tito took notice. On 16 June, he summoned a 'Congress of Patriots from Montenegro, the Bay of Kotor and Sandžak' which issued a declaration that did not refer to the communist organization, but praised the three big powers and made an appeal to the Yugoslav government-in-exile instead of attacking it. ${ }^{27}$ A few days later, on 19 June, he made a speech that all but abandoned the leftist tone of his previous statements and condemned the 'sectarianism' of the party. ${ }^{28}$

\footnotetext{
${ }^{23}$ From Vyshinskii to Dekanozov, 19.6.1942, in AVP RF, f. 06, o. 4, p. 26, d. 292, I. 93 and Jukic, Uncommon Cause, 260.

${ }^{24}$ Banac (ed.) The Diary of Georgi Dimitrov, 24.7.1942, 232.

${ }^{25}$ For example Zapis' besedy Prem'er-Ministra Iugoslavskogo Pravitel'stva v Emigratsii C. Iovanovich s Poslom SSSR pri Soiuznykh Pravitel'stvakh v Londone A.E. Bogomolovym, 16.5.1942 and Iz Doneseniia Posla SSSR v Velikobritanii I.M. Maiskogo v NKID SSSR, 28.7.1942, in Otnosheniia Rossii (SSSR) s Iugoslaviei, 117-18 and 127.

${ }^{26}$ Banac (ed.) The Diary of Georgi Dimitrov, 1.6.1942, 220-21. The importance of this directive for YugoslavSoviet relations is stressed by Jukic, Uncommon Cause, 233.

27 Jukic, Uncommon Cause, 251-52.

${ }^{28}$ Swain, Tito: a Biography, 47 and Gibianskii, 'lugoslaviia v Period Vtoroi Mirovoi Voiny', 428.
} 
The decision to take a public stand in Yugoslav affairs was finally agreed between Molotov and Dimitrov at the end of July. ${ }^{29}$ It was the result of several factors: the new line adopted by Tito, increasing reports of collaboration between Mihailović and the Italians, and the British veto of the conclusion of a treaty between Moscow and the Yugoslav government-in-exile as proposed by the Soviet government. ${ }^{30}$

Beginning in August 1942, the new Soviet course towards Yugoslavia developed in three directions. Firstly, on 3 August, a carefully worded memorandum that accused the Chetniks of fighting the Partisans in collaboration with the occupiers was presented to the ambassador of the Yugoslav government-in-exile in London. ${ }^{31}$

Secondly, Moscow kept diplomatic contacts with the Yugoslav government on a different track and, at the end of August, it expressed a desire to elevate relations to the level of establishing an embassy. Tito protested vehemently. ${ }^{32}$ At the end of November, much to the surprise of the Yugoslavs, Moscow also offered to send a military mission to establish direct contact with Mihailović. ${ }^{33}$

Thirdly, Dimitrov maintained a watchful eye over Tito to ensure that he stayed on track. A few days after the memorandum against Mihailović was handed to the Yugoslavs, Dimitrov instructed Tito not to call his brigades 'proletarian' but rather 'shock brigades' and urged him to understand that this had 'enormous political significance, both for consolidating people's forces against the occupiers and collaborators within the country and for foreign countries'. Dimitrov also reminded him that he was waging a people's liberation war and not a 'proletarian struggle', and that he should 'quit playing right into the hands of the enemies of the people, who will always make vicious use of any such lapses on your part' ${ }^{34}$ The haggling

\footnotetext{
${ }^{29}$ Banac (ed.) The Diary of Georgi Dimitrov, 29.7.1942, 233.

${ }^{30}$ The agreement was vetoed by the British out of concern that in the form proposed by the Soviets, which covered also the post-war period, it could create a precedent for the other governments in exile to ask for similar guarantees. Yugoslav-Soviet relation, R3643, in National Archives [NA], FO 371/33490.

${ }^{31}$ Pamiatnaia Zapiska NKID SSSR Iugoslavskoi Missii v SSSR, 3.8.1942, in Otnosheniia Rossii (SSSR) s Iugoslaviei, 130-31. The Soviets were concerned that the accusations did not appear to originate from the Communist side: significantly, when Molotov and Dimitrov agreed on the content of the memorandum, they also decided to retort to the expected Yugoslav objections with the declaration at the Congress of 16 June. Banac (ed.) The Diary of Georgi Dimitrov, 29.7.1942, 233.

${ }^{32}$ Radiogramma General'nogo Secretaria KPIu I. Broz Tito Ispolnitel'nomu Komitetu Kominterna, 8-9.9.1942, in Otnosheniia Rossii (SSSR) s Iugoslaviei, 138-39.

${ }^{33}$ The offer was rejected by the Yugoslavs, who insisted on a cessation of the Soviet propaganda campaign against the Chetniks. Clissold (ed.) Yugoslavia and the Soviet Union, 140.

${ }^{34}$ Paslanie G. Dimitrova Val'teru (I. Tito) i F. Birku (E. Kardeliu) o "Proletarskikh Brigadakh", 8.8.1942, in Narinski and Lebedeva (eds.) Komintern i Vtoraia Mirovaia Voina, Chast' II, posle 22 liunia 1941 g., 248 and in English translation in Banac (ed.) The Diary of Georgi Dimitrov, 10.8.1942, 234.
} 
continued for the rest of 1942 . When, in November, Tito informed Moscow that he intended to form 'something like a government', Dimitrov urged him not to give to this organization a partisan character, asking for the abolition of the monarchy or attacking the Government-inexile with which the Soviet Union had treaty relations. ${ }^{35}$ Again, Tito complied. When, at the end of November, he created the Anti-Fascist Council for the National Liberation of Yugoslavia (AVNOJ), he gave to it a very broad programme, with which almost everybody could identify.

The result of Moscow's intervention in Yugoslav affairs was the stalling of Soviet policies. The British military was increasingly unhappy with Mihailović, who was both refraining from any anti-Axis activity in order to avoid German reprisals on the population and in Montenegro had focused on fighting the Partisans in a "marriage of interest" with the Italians. The Foreign Office was also worried about the repercussions of its policy for Moscow. But the immediate support given to the Chetnik movement by the Yugoslav government limited the options at British disposal, and the Foreign Office rallied behind it to defend Mihailović. As a consequence, when the Yugoslavs presented a counter memorandum rebuffing the Soviet accusations, Moscow was unable to take the affair further without creating a breach with the British. Moreover, it could not substantiate its allegations and challenge the Yugoslav counter memorandum without using the information provided by Tito and thus revealing its contact with the Partisans. Various options were considered, including proposing to Tito an intervention by writing a letter to the editor of a journal, who would invite Mihailović to reply. ${ }^{36}$ But in the end, the Soviets decided not to reply at all and on 25 January 1943 they issued a brief note merely reaffirming the content of the August memorandum. ${ }^{37}$

In the following months, while Soviet relations with Tito were punctuated by occasional disagreements and complicated by Tito's frustration with the lack of Soviet military support, ${ }^{38}$

\footnotetext{
${ }^{35}$ Radiogramma General'nogo Sekretariia KPlu I. Broz Tito Ispolnitel'nogo Komitetu Kominterna, 12.11.1942, and Radiogramma General'nogo Sekretariia Ispolnitel'nogo Komiteta Kominterna G. Dimitrova Generaln'nomy Sekretariu KPIu I. Broz Tito, 19.11.1942 in Otnosheniia Rossii (SSSR) s lugoslaviei, 149 and 154 and Firsov, Klehr, and Haynes, Secret Cables of the Comintern, 196-97.

${ }^{36}$ From Lozovskii to Molotov, 29.8.1942, in AVP RF, f. 06, o. 4, p. 26, f. 292 II. 145-146.

${ }^{37}$ Pamiatnaia Zapiska NKID SSSR Iugoslavskoi Missii v SSSR, 25.1.1943, in Otnosheniia Rossii (SSSR) s Iugoslaviei, 170.

${ }^{38}$ A low point was reached in March 1943, when Tito notified the Soviets that he had established contact with the Germans to exchange prisoners, adding with a certain pleasure that hatred for the British was running high among the people of Yugoslavia because they refused to open a second front and were 'striving to weaken the Soviet Union'. Radiogramma General'novo Sekretaria KPlu I. Broz Tito Ispolnitel'nomu Komitetu Kominterna, 30.3.1943, in ibid., 182. The Soviets were indignant and strongly reprimanded him. Dimitrov caustically suggested to Tito that the interests of the national liberation struggle might be better served 'by stirring up the
} 
Moscow seemed to be unsure as to whether it was better openly to support the Partisans, work for an agreement with the Chetniks, or simply remain steadfast in their policy of denial. On 5 March 1943, for example, the British government asked Moscow for support in getting in touch with the Partisans. ${ }^{39}$ Molotov's first reaction was, as usual, to deny the existence of any connections with Yugoslavia, ${ }^{40}$ but then he pondered over whether it might be expedient to present a more articulate reply. The several different drafts of his response which were prepared are indicative of the doubts which were harboured in Moscow.

A first version, dated 31 March, stated that the Soviet Union considered unification of all the forces which were fighting against the Germans to be of utmost importance. The draft also contained a cautious expression of support for the partisan movement 'which encompassed the very broadest sectors of the population irrespective of political orientation'. However, the document continued, the Soviet government did not wish to interfere in internal problems that needed to be sorted out by the Yugoslav government. It denied that it was supporting the Partisans against Mihailović or producing propaganda against him. A second version of the document, prepared on 4 April, dropped the call for unification of the resistance forces and the claim that Soviet radio was not attacking Mihailović, emphasizing that 'there should be no recrimination in the British and Soviet press and radio, either against Mihailović or the Partisan'. On 16 April, it was decided to delay the reply and indeed it was never sent. ${ }^{41}$

In the meantime, British policy was shifting. British intelligence in Cairo seemed increasingly convinced that the Partisans were a better investment from a military point of view, and started lobbying to establish liaisons with them. In March, they also sent their first agent to Tito's headquarters. Over the summer, it was decided to support both groups and to send them two high ranking missions to evaluate the situation and advise on policy. Moscow remained suspicious. When, in May, one of the British agents despatched to his headquarters

\footnotetext{
utmost hatred for the occupiers' instead of 'encouraging displeasure with the English'. Banac (ed.) The Diary of Georgi Dimitrov, 1.4.1943, 267.

39 Memorandum Pravitel'stva Velikobritannii Pravitel'stvu SSSR, 9.3.1943, in Otnosheniia Rossii (SSSR) $s$ Iugoslaviei, 176-87.

${ }^{40}$ Telegramma Posla Iugoslavii v SSSR S. Simicha v Ministerstvo Inostrannykh del lugoslavskogo Pravitel'stva v Emigratsii, 20.3.1943, in ibid., 181-82.

${ }^{41}$ The various drafts are in AVP RF, f. 06, o. 5, p. 35, f. 421, II. 9-16. See also ibid., 524.
} 
asked Tito to send a delegation to Cairo, Stalin himself agreed with Dimitrov that the request should be turned down on the grounds that everybody was busy fighting the enemy. ${ }^{42}$

Moscow's paralysis lifted at the end of 1943, in the context of the transition in Soviet policy towards the entire communist movement. In May, Moscow had announced the disbandment of the Comintern. Although this move is generally interpreted as an attempt to improve relations with the Western Allies, privately Stalin explained that it was also designed to enlarge the field of manoeuvre of the communist parties which, due to their participation in the Comintern, were 'falsely accused of supposedly being agents of a foreign state'. ${ }^{43}$ In June it was decided to create a Department of International Information, a sort of umbrella organization secretly headed by Dimitrov which was in charge of "special institutes" that inherited the functions of the Comintern. ${ }^{44}$ What happened later, however, was a much greater change. Although the institutes were created immediately, the Department that was supposed to control them was not, and its functions were approved only in September 1944. In the meantime, the institutes apparently operated without much direction from the centre, and were severally handicapped by organizational problems and by the fact that most foreign cadres were going back to their own countries. Dimitrov, who in any case had to take frequent periods of leave due to illness, was progressively side-lined, while Stalin and Molotov personally directed the communist parties either through personal meetings with their leaders or through the missions dispatched by Soviet military intelligence.

In the meantime, in Yugoslavia the pace of events began to accelerate. Tito had good reason to think that, in the Western field, the wind was changing in his favour. The British, he cabled to Dimitrov, were offering help 'now that we have almost liquidated Mihailović and his Chetniks' and it was necessary to accept their offer of material aid 'and win them over politically'. ${ }^{45}$ Tito's impression that the standing of the Partisans was improving was confirmed when one of the British agents told him that in Cairo there were two factions, one

\footnotetext{
42 From Dimitrov to Stalin, 24.5.1943, in Russian State Archive of Socio-Political History [RGASPI], f. 495, o. 74, d. 595, I. 30. Stalin's approval is clear from the 26 May entry in Dimitrov's diary, which has not been included in the English translation edited by I. Banac but appears in the Italian edition.

${ }^{43}$ Banac (ed.) The Diary of Georgi Dimitrov, 21.5.1943, 276.

${ }^{44}$ On the creation of the Department of International information M.M. Narinskii and N.S. Lebedeva, 'Rospusk Kominterna i Sozdanie Otdela Mezhdunarodnoi Informatsii TsK VKP(b). Mai 1943 - Mai 1945', in A. O. Chubar'ian (ed.) Istoriia Kommunisticheskogo Internatsionala. 1919-1943: Dokumental'nie Ocherki (Moscow 2002), 227-53 and G.M. Adibekov, 'Komintern posle Formal'nogo Rospuska (1943 1944 gg.)', Voprosy Istorii, 8 (1997), $28-41$.

${ }^{45}$ From Dimitrov to Tito, 16.5.1943, in RGASPI, f. 82, o. 2, d. 1369, II. 25-26.
} 
pro-Mihailović and one pro-Tito, but that the military circles were unhappy with British support for the former. Tito quickly passed this information to Dimitrov, adding that 'the British 'wants to know too much about our army' but that he was giving them only 'the information that we think can be given' ${ }^{46}$ During the same period, Tito pushed neighbouring parties to take a more aggressive stand against their internal enemies. In August, he forced the Albanian communist party to denounce an agreement with the nationalists of the Balli Kombëtar, thus escalating the confrontation with non-communist groups. At the same time, he extracted from the Greek communist party the right to organize a Slav National Liberation Front in Greek Macedonia, which soon manifested separatist tendencies. In September, he sharply criticised the Greek comrades for allowing their national liberation movement to fall under British influence. ${ }^{47}$ Finally, on 2 October, Tito informed Dimitrov that he did not recognise the authority of the government-in-exile or the King, that he did not intend to allow their return to the country, and that the AVNOJ should be considered the only legal authority in the country. Significantly he reported that he had communicated his intentions to Fitzroy Maclean, Churchill's personal envoy to the Partisans, and that Maclean had let the Partisans know that the British government would not strongly uphold the king and the governmentin-exile. ${ }^{48}$ Although the telegram was widely circulated among the Soviet leadership, which had strongly discouraged Tito to take the same step a year earlier, this time Moscow did not react. Excluding the argument that the implications of this news had not been fully understood, it can be argued that Moscow preferred to remain on the fringe of the action, keeping a free hand to stop Tito if his gamble backfired or to support him in case of success. Which, in the end, is exactly what happened.

The Soviets' silence, in any case, was enough for Tito to start preparing a new conference of the AVNOJ without feeling the need to keep them updated on the details. At the same time, Moscow started conducting discreet surveys with the British. At the end of October, meeting with Eden in Moscow, Molotov inquired cautiously about the possibility of sending

\footnotetext{
${ }^{46}$ Radiogramma I. Broz Tito G. Dimitrovu, 1.9.1943, in Otnosheniia Rossii (SSSR) s Iugoslaviei, 192-93.

${ }^{47}$ Fischer, Albania at War, 149-52, J. Koliopoulos, Plundered Loyalties: Axis Occupation and Civil Strife in Greek West Macedonia, 1941-1949 (London 1999), 114-33 and Palmer and King, Yugoslav Communism and the Macedonian Question, 104.

${ }^{48}$ Radiogramma I. Broz Tito G. Dimitrovu, 2.10.1943, in Otnosheniia Rossii (SSSR) s lugoslaviei, 193-94. The copy of the document in RGASPI, f. 82 , o. 2, d. 1369, I. 29 is dated 8 October. Is it also possible that Tito exaggerated Maclean's assurance to be sure of getting Moscow's support, as suggested in ibid., 535.
} 
a Soviet mission to the Partisans 'to obtain information' ${ }^{49}$ But when Eden endorsed the idea and suggested sending a Soviet mission to the Chetniks as well, Molotov simply dropped the proposal. ${ }^{50}$ At the same meeting, in response to Eden's direct question, he did not deny that Moscow had wireless communication with the country. He added, however, that it 'gave only a very limited and uncertain means of contact. ${ }^{51}$ A request from Manuil'skii to send substantial military help to Tito now that the military situation made it technically possible was also kept on hold. ${ }^{52}$ Moscow was clearly waiting to see how the situation developed.

The Soviets did not have to wait long. At the beginning of November 1943, Maclean suggested to abandon the Chetniks, who were considered irremediably compromised by the Germans, and to give full support to Tito. Churchill embraced the idea that instead of trying to reconcile Tito and Mihailović, it was better to embrace the former, in the hope of gaining his confidence and leading him into an agreement with the king. At Tehran, the British informed Moscow that they intended to provide military support to Tito and dropped their request for assistance in brokering a deal between him and Mihailović. Soviet intelligence confirmed the British shift towards Tito, providing Moscow with London's confidential documents on the matter. ${ }^{53}$ The question of the Soviet mission was discussed again. Since the meeting in Moscow in October, however, positions had been reversed. This time it was Molotov who asked Eden 'if he thinks that we should send a mission also to Mihailović', and it was the British foreign minister who raised objections based both on technical reasons and on the fact that they were about to abandon the chief of the Chetniks. ${ }^{54}$ Already on his way back from the conference, Stalin instructed the chief of Soviet aviation to support the Partisans 'whatever it takes'. ${ }^{55}$

\footnotetext{
${ }^{49}$ Tito had been constantly requesting a Soviet mission since May 1943. Radiogramma General'nogo Secretaria KPIu I. Broz Tito General'nomu Secretariiu Ispolnitel'nogo Kominterna G. Dimitrovu, 24.5.1943, published in ibid., 188.

${ }^{50}$ Iz Zapisi Besedy Narodnogo Komissara Inostrannykh del SSSR V.M. Molotova s Ministrom Inostrannykh Del Velikobritannii A. Idenom, 30.10.1943, in ibid., 198.

${ }^{51}$ From Moscow to Foreign Office, 31.10.1943, in NA, HS 5/925.

52 In October Dimitrov was sick and Manuil'skii was acting on his behalf. From Manuil'skii to Stalin, 17.10.1943 in RGASPI, f. 82, o. 2, d. 1369, II. 30-31 and Edemskii, 'Moskva i Antifashistskoe Dvizhenie I. Broz Tito', 99.

53 Ibid.,

${ }^{54}$ Zapis' besedy tov. Molotova s Idenom i Gopkinsom vo Vremia Zavtraka v Angliiskoi Missii v Tegerane. 30 Noiabria 1943 goda, in O.A. Rzheshevskii (ed.) Stalin i Cherchill': Vstrechi. Besedy. Diskussii: Dokumenty, Kommentarii: 1941-1945 (Moscow 2004), 397 and From Foreign Office to Moscow, 18.12.1943, in NA, FO $536 / 8 / 21$.

${ }^{55}$ Quoted in Pirjevec, Tito e i suoi Compagni, 151.
} 
Tito, in the meantime, made his move. On 29 November, the AVNOJ established itself as the provisional government of the country and declared that the king could not enter the country until it had been liberated and a referendum held on the monarchy. ${ }^{56}$ Apparently, Stalin reacted angrily to the news, commenting that it was 'a stab in the back for the Soviet Union and the Teheran decisions' ${ }^{57}$ Even if this was the case, Stalin quickly changed his tune once it was clear that the Western allies did not view this development in a negative light. On 12 December, the proposal for military supplies to Tito put forward in October by Manuil'skii was finally approved. On 13 December, the British wrote to Moscow informing them that they did not consider the results of the AVNOJ conference would affect their Yugoslav policy or relations with the partisans, and asked for Soviet assistance in brokering an agreement between Tito and the king. ${ }^{58}$ The following day the Soviet Minister of Foreign Affairs issued a note praising the AVNOJ's decisions. The wording of the note made it clear that the new policy had originated in the Western field, and that Moscow was merely following up a British initiative. The crucial passage, which was rewritten several times, stated that the events in Yugoslavia had 'already met sympathetic responses in the United Kingdom and in the US' and in announcing the arrival of a Soviet Mission it was stressed that the British had already established their mission in the field. ${ }^{59}$ The Soviet reply to the British note of 13 December was also carefully worded to keep the Soviets' hands free. Assurances that the Soviet mission would facilitate cooperation between Tito and the king contained in the first draft of the response were dropped in the final version. In the end, Molotov simply stated that, although there appeared to be many obstacles, the Soviet government was 'ready to do everything possible for the achievement of a compromise' ${ }^{60}$ The last piece of the new Soviet policy was put in place on 22 December, when the government in Moscow communicated to the

\footnotetext{
${ }^{56}$ Radiogramma TsK KPIU G. Dimitrovu, 30.11.1943, in Otnosheniia Rossii (SSSR) s Iugoslaviei, 206.

57 Clissold (ed.) Yugoslavia and the Soviet Union, 27. The relevance of this episode is disputed by Jukic, Uncommon Cause, 320-26.

58 Memorandum Previtel'stva Velikobritanii Pravitel'stvu SSSR, 13.12.1943, in Otnosheniia Rossii (SSSR) $s$ Iugoslaviei, 207-08.

${ }^{59}$ Soobshchenie Informbiuro NKID SSSR o Sobytiiakh v lugoslavii, 14.12.1944, in ibid., 208.

${ }^{60}$ Memorandum, 20.12.1043, in AVP RF, f. 06, o. 5, p. 35, d. 421, I. 33. The first draft in AVP RF, f. 06, o. 5, p. 35, d. 420, I. 31.
} 
Yugoslav government-in-exile that it was not ready to sign the new friendship and mutual assistance pact that had been under discussion since $1942 .{ }^{61}$

In the following days, Moscow proved to be more than happy to leave the British out in the cold: when Eden asked Molotov if the Soviet government had any suggestions as to how to achieve the political compromise, he replied that unfortunately Moscow had not received enough information about the situation on the ground to make specific recommendations. ${ }^{62}$ Meanwhile, Dimitrov instructed Tito as to how he should reply to the question posed by the Western Allies to the Yugoslav delegation that was sent to Cairo at the beginning of December. Dimitrov agreed with Tito that he should not push for recognition of the committee by the Western Allies and that he should remain firm in his demand to postpone the issue of the position of the king until after the war. On the issue of propaganda against the king, he suggested that Tito show 'the necessary flexibility' in order to 'better [disorganize] his supporters abroad and in Serbia' and overcome 'certain difficulties on the part of the Anglo-Americans in their aid to the People's Liberation Army'. Tito, for example, could declare that if the king will not oppose the national committee, the latter will for its part refrain from all propaganda against the king'. Above all, it was necessary to avoid giving the impression that he was favouring the Croats over the Serbs. ${ }^{63}$

At the beginning of 1944 , the Soviets continued to claim that they did not have enough information about the situation in Yugoslavia to take any action, and under this pretext they refused to issue a declaration advocating an agreement between Tito and the king. ${ }^{64}$ Behind the scenes, they were overturning one of the key features of the popular front strategy established in 1941, suggesting to Tito that he reject any agreement with the Yugoslav government-in-exile. It was Churchill who took the initiative, asking Tito, on 5 February, if the dismissal of Mihailović could open up the possibility of an agreement between the Partisans

\footnotetext{
${ }^{61}$ Zapis' Besedy Prem'er-Ministra i Ministra Inostrannykh del lugoslavskogo Pravitel'stva v Emigratsii B. Puricha $s$ Poslom SSSR pri lugoslavskom Pravitel'stve v Emigratsii v Kaire N.I. Novikovym, 22.12.1943, in Otnosheniia Rossii (SSSR) s lugoslaviei, 211-12.

${ }^{62}$ From Balfour to Molotov, 24.12.1943 and from Molotov to Balfour, 30.12.1943, in AVP RF f. 06, 0. 5, p. 35, d. 421 II. 35-37.

${ }^{63}$ Radiogramma I. Broz Tito G. Dimitrovu, 25.12.1943, in Otnosheniia Rossii (SSSR) s lugoslaviei, 214 and Banac (ed.) The Diary of Georgi Dimitrov, 28.12.1943, 292.

${ }^{64}$ From Balfour to Molotov, 14.1.1944, and from Molotov to Balfour, [18.1.1944], in AV PRF, f. 06, o. 6. p. 33, d. 383, II. 6-7 and 8-9 and Beseda s Angliiskim Poslom pri lugoslavskom Pravitel'stve Stivensom. 11 lanvaria 1944, 22.1.1944, in AV PRF, f. 06, o. 6, p. 57, d. 792, II. 9-10.
} 
and the king. Tito forwarded the letter to Dimitrov, pointing out that although he had plenty of reasons to refuse the deal the matter was serious enough to ask the opinion of Stalin himself. ${ }^{65}$ Tito, who was used to being reprimanded by Moscow over his direct confrontations with the Government-in-exile, this time received a different response. Though Dimitrov, Stalin and Molotov let him know that he should reply to 'the Englishman' that he too favoured the unity of the Yugoslavs and that, for this reason, the government-in-exile, including Mihailović, should be eliminated, the AVNOJ recognized as the sole government of Yugoslavia and the king submitted to its law. If the king was willing to accept these conditions, they stated, the AVNOJ would not object to cooperating with him, but of course the ultimate fate of the monarchy would only be decided after the end of the war. Tito was also instructed to refer to Stalin in the subsequent telegrams as to 'the friend' ${ }^{66}$

Tito wrote his reply to Churchill on 9 February, using the wording of the text he had received from the Kremlin. ${ }^{67}$ Apparently, when the British Ambassador in Moscow showed the messages exchanged between Tito and Churchill to Molotov, the Soviet foreign minister commented along the lines that they 'had not advanced things much'. ${ }^{68}$ British policy had reached an impasse. Lacking a political solution, it was clear to everybody that the crucial factor for the future of Yugoslavia was the balance of forces in the field and especially in Serbia where Mihailović was still strong and the Partisans did not have a significant presence.

At the end of February, the possibility of Soviet action in Yugoslavia substantially increased with the arrival of the Soviet military mission. The mission, led by the LieutenantGeneral of the military intelligence, Nikolai Korneev, was composed of 21 members, including at least two members of the KGB, whose task was to report, among other things, on the intentions of the British and the Americans in Yugoslavia. At Tito's request, in April an additional group of KGB agents was dispatched to train the partisans in the intelligence field. ${ }^{69}$ In the following months, the ranks of the mission were further increased, and by October

\footnotetext{
${ }^{65}$ Rasshifrovannaia Telegramma iz Iugoslavii, 8.2.1944, in RGASPI, f. 82, o. 2, d. 1369, II. 56-57.

${ }^{66}$ Radiogramma G. Dimitrova Predsedateliu Natsional'nogo Komiteta Osvobozhdenia Iugoslavii I. Broz Tito, 9.2.1944, in Otnosheniia Rossii (SSSR) s Iugoslaviei, 219 and in English translation in Banac (ed.) The Diary of Georgi Dimitrov, 9.2.1944, 298-299.

67 Gibianskii, 'lugoslaviia v Period Vtoroi Mirovoi Voiny', 462, Jukic, Uncommon Cause, 358-60 and Edemskii, 'Moskva i Antifashistskoe Dvizhenie I. Broz Tito', 102.

${ }^{68}$ From Moscow to Foreign Office, R3301, 29.2.1944, in NA, FO 371/44249.

69 Spisok Lichnogo Sostava Sovetskoi Voennoi Missii v lugoslavii, 3.3.1944, in Russkii Arkhiv: Velikaia Otechestvennaia. Krasnaia Armiia v Stranakh Tsentral'noi, Severnoi Evropy. Dokumenty i Materialy. 1944-1945, 187-88 and Edemskii, 'Moskva i Antifashistskoe Dvizhenie I. Broz Tito', 105.
} 
1944 it numbered 94 members, including 32 medical personnel. ${ }^{70}$ The importance attached to the mission by the Soviets was also reflected in the rank of Korneev, a Lieutenant-General, who outranked both the heads of the British and the American missions attached to the partisans. $^{71}$

Officially, the mission was there only to gather information on the country. ${ }^{72}$ It did much more than this. Firstly, the mission, which reported directly to Molotov, created for the first time a direct channel of communication between Tito and the Soviet leadership when Moscow wanted to be sure that the situation was developing in line with its foreign policy.

Completing the process of side-lining Dimitrov which had started with the disbandment of the Comintern, Tito was informed that from April he could communicate directly with Molotov, and that Dimitrov would have nothing more to do with Yugoslavia. Soviet correspondence with Tito shows that starting from 1944 the Soviet leadership was not only concerned to reassure the Western Allies, but also to reassure Tito, who was clearly emerging as the master of post-war Yugoslavia. In the same letter which confirmed the marginalization of Dimitrov, Stalin and Molotov personally assured Tito that they considered Yugoslavia an ally of the Soviet Union, and Bulgaria an enemy, and that even if the situation changed in Bulgaria they wanted Yugoslavia to be their 'principal support in South-eastern Europe'. The two leaders added that they had no plans for the 'sovietisation' of either Yugoslavia or Bulgaria, which they characterised as democratic countries allied with the Soviet Union, and that whatever Dimitrov was thinking, any decision on the question of Macedonia would be taken with Tito's agreement. ${ }^{73}$ From April 1944 onwards, the tone of Soviet correspondence with Tito changed significantly. While Dimitrov had addressed Tito as a subordinate, Molotov generally expressed himself in terms of giving advice rather than directives. In June, Korneev was also reminded that he should make suggestions to Tito only when he was asked to do so,

\footnotetext{
${ }^{70}$ Poimennyi Spisok Lichnogo Sostava Sovetskoi Missii v lugoslavii na Nachalo Oktiabria 1944 Goda, in Sergienko, Okazanie Sovetskim Soiuzom Voenno-Tekhnicheskoi i Kadrovoi Pomoshchi lugoslavii v Gody Vtoroi Mirovoi Voiny, 523

71 Russian Military Mission to Marshal TITO of Jugoslavia, 31.1.1944, in National Archives and Records Administration [NARA], RG 226, Entry 190, box 72, folder 15.

72 Soobshchenie Informbiuro NKID SSSR o Sobytiiakh v lugoslavii, 14.12.1944, in Otnosheniia Rossii (SSSR) $s$ lugoslaviei, 208.

${ }^{73}$ Alekseev to Korneev, 15.4.44, in RGASPI, f. 82, o. 2, d. 1369, I. 129. The letter is incorrectly dated September 1944 in ibid., 296-97. See also Edemskii, 'Moskva i Antifashistskoe Dvizhenie I. Broz Tito', 109-110.
} 
and that he should not overwhelm him with questions 'especially when he shows no desire to express an opinion'. ${ }^{74}$

Besides establishing a political connection, the second task of the mission was to create the conditions for the delivery of a vital military supply to the Partisan army. On 4 March, Molotov guaranteed that as soon as this was technically possible, Moscow would send antitank cannons, anti-aircraft machine guns, ammunition, food, radio sets, typewriters, cinema projectors with movies, cameras 'and also Soviet literature'. Only with the provision of antiaircraft weapons did there seem to be difficulties, but Molotov promised a further reply on this matter 'within two days'. Molotov also assured Tito that he would provide him with experts in intelligence, counterintelligence, and cipher communications, as well as financial experts. Tito's request for two Soviet officers to be posted in each of the Yugoslav corps was also approved, as well as the dispatch of a Yugoslav mission to Moscow. ${ }^{75}$ Moscow clearly felt a sense of urgency, especially after Tito suggested that the British were not supporting his divisions in western Serbia because they were also fighting against Mihailović. In mid-March, Molotov noted that it was necessary to do 'everything possible' to help them. ${ }^{76}$ The Yugoslav mission to the Soviet Union arrived in Moscow in April. It included Milovan Djilas, who was one of the key members of Tito's staff.

The delivery of military supplies to Yugoslavia, however, was more problematic than both the Soviets and the partisans had hoped and expected, and certainly did not immediately result in a partisan breakthrough in Serbia. At the end of April, Manuil'skii informed Molotov that with only six aircraft deployed for this purpose, it had not been possible to deliver even the small load of essential supplies assembled in Kiev. ${ }^{77}$ The Soviet Air Force justified its actions, claiming that bad weather, lack of aircraft, and excessive distance from the dropping

\footnotetext{
${ }^{74}$ From Alekseev [Molotov] to Korneev, 17.6.44, in RGASPI, f. 82, o. 2, d. 1370, I. 84 and also From Korneev to Mel'nikov and others, 18.8.1944, in RGASPI, f. 82, o. 2, d. 1731, I. 122. Although evidence on the internal Soviet debate is extremely scant, it is possible that, over the course of 1944, the civil and military Soviet leadership had different views on how to establish relations with Tito. In November 1944, the head of the Soviet military intelligence Ivan Il'ichev sharply attacked Korneev, claiming that although at the end of October he had been instructed to act otherwise by Molotov, he was maintaining an obliging attitude towards Tito, and had turned the mission 'in a sort of appendage' of the Yugoslav headquarters. From Il'ichev to Molotov, 23.11.1944, in RGASPI, f 82, o. 2, d. 1373, II. 1-2. Korneev was eventually replaced by Major General Anisim Kiselev. It is also possible that Il'ichev resented that fact that Korneev reported to Molotov and not to him.

${ }^{75}$ From Alekseev [Molotov] to Korneev, 4.3.1944, in RGASPI, f. 82, o. 2, d. 1369, I. 82.

${ }^{76}$ Handwritten note on Rasshifrovannia Telegramma iz lugoslavii, 17.3.1944, in RGASPI, f. 82, o. 2, d. 1369, I. 97.

${ }^{77}$ Dokladnaia Zapisca D.Z. Manuil'skogo Zamestiteliu Predsedatelia Sovnarkoma SSSR ob Okazanii Pomoshchi Narodno-Osvoboditel'noi Armii lugoslavii, 24.4.1944, in Russkii Arkhiv: Velikaia Otechestvennaia. Krasnaia Armiia v Stranakh Tsentral'noi, Severnoi Evropy. Dokumenty i Materialy. 1944-1945, 192-94.
} 
points were the primary reasons for the poor results. Apparently, lack of coordination with the Soviet mission was also to blame: as one officer who was responsible for organizing the operations claimed, Korneev had an inadequate understanding of how the delivery of supplies worked, and had submitted a plan with dropping points extending across $500 \mathrm{~km}$, 'which would be across the entire country'. ${ }^{78}$ In one instance, a plane had been accidentally downed by Soviet friendly fire. ${ }^{79}$ At the beginning of May, the State Defense Committee approved the allocation of additional crews for the delivery of supplies and the establishment of another base in the Ukrainian region of Vinnytsia. Efforts were also intensified to obtain permission from the Western Allies to operate Soviet planes out of their base in southern Italy, and the situation slowly improved. Between May and July, according to the Korneev's report, Soviet planes delivered over 220 tons of material, including around 150 tons of military equipment, to Yugoslavia. ${ }^{80}$

While doing their best to help the Partisans, Molotov and Stalin remained determined that Tito's increasing hold over the country did not appear to be orchestrated by Moscow. KGB officers attached to the mission were instructed to keep a low profile and demonstrate 'extreme caution and tact so as not to provoke complains that we are interfering in the internal affairs of Yugoslavia or that we are not loyal to the allies' ${ }^{81}$ The same caution encouraged Moscow to reject the option to sever relations with the Yugoslav government-inexile, which had been contemplated in the first months of the year. ${ }^{82}$ In April, meeting Djilas in Moscow, Molotov guaranteed that the Soviet government intended to recognize the AVNOJ as the legitimate government of Yugoslavia, but he also made it clear that this step was premature and that it should be done with consideration for relations with the Western Allies and the situation in other countries. Although Djilas was pushing for a quick solution, both he and Molotov agreed that international recognition depended on the capacity of Tito

\footnotetext{
${ }^{78}$ O Perebroske Gruzov Narodno-Osvoboditel'noi Armii lugoslavii, 17.4.1944, in RGAPSI, f. 82, o. 2, d. 1369 , II. 140-146.

${ }^{79}$ Edemskii, 'Moskva i Antifashistskoe Dvizhenie I. Broz Tito', 106-7.

${ }^{80}$ Postanovlenie GKO SSSR n. 5847ss ot 8 Maia 1944 Goda 'o Meropriatiax po Okazaniu Pomoshi NOAlu', in Sergienko, Okazanie Sovetskim Soiuzom Voenno-Tekhnicheskoi i Kadrovoi Pomoshchi lugoslavii v Gody Vtoroi Mirovoi Voiny, 474-75 and Perechen' Vidov Imushchestva, Sbroshennogo Nashimi Samoletami v lugoslavii za Period s 4 Maia po 1 Avgusta, in RGASPI, f. 82, o. 2, d. 1731, II. 37-39.

${ }^{81}$ Quoted in Edemskii, 'Moskva i Antifashistskoe Dvizhenie I. Broz Tito', 105.

${ }^{82}$ Drafts of the letters directed to the Yugoslav Prime Minister and dated 30.1.1944 and 12.3.1944 in AVP RF, $\mathrm{f}$. $06,0.6$, p. 57, d. 791 , II. 1-6.
} 
to strengthen his position in Serbia. ${ }^{83}$ As was often the case when Moscow wanted to send a signal without making an official commitment, the question of political recognition for the AVNOJ by the Soviet government was repeatedly posed by the Soviet press in the weeks that followed. ${ }^{84}$

The Western Allies remained a continuous source of concern. Tito and the Soviets became increasingly suspicious that, notwithstanding Churchill's public statements, the British were still surreptitiously supporting Mihailović in the hope of turning his forces against the Partisans. ${ }^{85}$ By the beginning of June, Stalin was also convinced that the British were plotting to kill Tito. When he barely survived a surprise attack by the Germans and was evacuated to Bari, Stalin summoned Djilas and asked him to warn Tito to be "wary of our "foreign friends"' and keep the details of his return trip strictly secret. 'Do not forget that there are cases where planes break down in the air', he said, in an apparent reference to the rumours that the death in a flying accident of the Polish general Sikorski had been orchestrated by London. ${ }^{86}$ Tito, as Stalin explained to Djilas, had to strengthen his security measures, creating a fake headquarters where he could invite the members of the foreign missions but where nothing of significance would actually be discussed. Real decisions were to be taken instead at a secret headquarters, whose existence was to remain unknown. It would be even better, he argued, to create a third headquarters, which would assume control over operations in the event that the real headquarters was compromised. Tito was also to find a way to reduce the number of Western agents attached to his troops, for example by telling the British that if they did not reduce their staff, he would be forced to agree to an increase in Soviet agents. Of course, Soviet agents could remain with Tito pretending that they were part of the Yugoslav army. Finally, Stalin suggested, Tito needed to find a way temporarily to fake good relations with King Peter 'to foster the appearance of cooperation with those who control him and make

\footnotetext{
${ }^{83}$ Iz Zapisi Besedy Narodnogo Komissara Inostrannykh del SSSR V. Molotova s Chlenom Verkhovnogo Shtaba HOA i POlu M. Dzhilasom I Nachal'nikom lugoslavskoi Voennoi Missii v SSSR V. Terzevichem, 24.4.1944, published in Otnosheniia Rossii (SSSR) s lugoslaviei, 237-40. Djilas does not mention this conversation in his memoirs. Djilas, Conversations with Stalin. See also Jukic, Uncommon Cause, 369-70.

${ }^{84}$ Otnosheniia Rossii (SSSR) s Iugoslaviei, 552.

${ }^{85}$ For example Soobshchenie Rezidentura NKGB SSSR o Politike Anglii v Otnoshenii Iugoslavii, 31.5.1944, in Organy Gosudarstvennoi Bezopasnosti SSSR v Velikoi Otechestvennoi Voine, tom 5, kniga 1 (2007), 488.

${ }^{86}$ Radiogramma Chlena Verkhovnoga Shtaba HOA i POlu, Chlena lugoslavskoi Voennoi Missii v SSSR M. Dzhilasa Predsedateliu HKOIU, Verkhovnomu Glavnokomanduiushchemu HOA i POlu Marshalu I Broz Tito, 5.6.1944, in Otnosheniia Rossii (SSSR) s Iugoslaviei, 265.
} 
them stop harming AVNOJ'. This was necessary 'to strengthen relations with the broad sectors of the population in Yugoslavia and, in particular, in Serbia' ${ }^{87}$

Djilas proved sceptical about the possibility of an agreement with the King, but in the end the situation developed as the Soviet leader had hoped. When, at the beginning of June 1944, Tito established his headquarters on the island of Vis to escape German pressure, the British found the occasion propitious for a meeting with the new Yugoslav prime minister, Ivan Šubašić. Molotov was informed by the British of the meeting, but before replying rushed to ask Tito's opinion and plans. Then, he put all Moscow's might into the negotiations and handed to Korneev a letter addressed to Šubašić, in which they promised to support a government formed in agreement with Tito and which unified the various forces against traitors of the people 'such as Pavelić, Nedić and Mihailovićs ${ }^{88}$. They also promised substantial financial help, ${ }^{89}$ and warned Tito that that the presence of the Soviet mission in Yugoslavia might arouse British suspicions and therefore worsen their relations with Tito. If at any point Tito began to think that this was the case, Moscow was ready to reduce the size of the mission leaving behind only a few minor figures. ${ }^{90}$ The agreement between Tito and Šubašić was signed on 16 June. The AVNOJ was recognized as the only legitimate government in Yugoslavia and Šubašić agreed to form his new administration without those elements compromised by the German occupation. The question of the monarchy was postponed until the end of the war.

The signing of the pact did not ease Moscow's concern. The KGB, which intercepted a report by Churchill on this matter, informed Stalin that neither the Prime Minister nor the British Foreign Office was fully satisfied, and that the conservative circles in the British Foreign Office were working against Tito, claiming that he did not have enough support in Serbia. In his report to Stalin, Korneev sounded similarly alarmed notes, claiming that British support to the Partisans was more fictitious than real, that the British had not really broken off relations with Mihailović and that they were secretly mobilizing all their reactionary forces to oppose

\footnotetext{
${ }^{87}$ From Alekseev [Molotov] to Korneev, 12.VI.44, in RGASPI, f. 82, o. 2, d. 1370, II. 79-80. See also A.B. Edemskii, 'The Role of Milovan Djilas in Soviet-Yugoslav Relations, 1944-1954', in V. Pavlović (ed.) The Balkans in the Cold War: Federations, Cominform, Yugoslav-Soviet Conflict (Belgrad 2011), 189.

${ }^{88}$ From Alekseev [Molotov] to Korneev, 12.6.1944, in RGASPI, f. 82, o. 2, d. 1370, I. 81 and Poslanie Narodnogo Komissara Inostrannykh Del SSSR V.M. Molotova Prem'er-Ministru Iugoslavkogo Pravitel'stva v Emigratsii I. Shubashichu, 15.6.1944, in Otnosheniia Rossii (SSSR) s lugoslaviei, 270.

89 Soglashenie o Zaime, Predostavliaemom Pravitel'stvom SSSR Natsional'nomu Komitetu Osvobozhdeniia lugoslavii, 16.6.1944, ibid., 271.

${ }^{90}$ From Alekseev [Molotov] to Korneev, 17.6.44, in RGASPI, f. 82, o. 2, d. 1370, I. 84.
} 
the Partisan army in the event of a German withdrawal. ${ }^{91}$ The British, who had cultivated the illusion of having tied Tito to an agreement for the restoration of the monarchy, were indeed disappointed, sensing that they were just giving Tito what he wanted without any reasonable concessions on his side. ${ }^{92}$ But as Eden had commented at the beginning of June, the British only had themselves to blame for this situation, as 'the Russians have merely sat back and watched us doing their work for them' ${ }^{93}$ At the same time, the Foreign Office vetoed a SOE plan to re-establish connections with Mihailović out of fear of losing Tito's confidence, and for the same reasons the British also forced the Americans to withdraw the intelligence mission they still maintained with the Chetniks. ${ }^{94}$

Tito considered the agreement with Šubašić exactly for what it was: an expedient to gain time, maintain good relations with the Allies and strengthen his position. Accordingly, at the beginning of July he wrote to Molotov and Stalin that he intended to delay the formation of the government 'because this would give us time to strengthen our position in Serbia'. ${ }^{95}$

In August, Tito gave further guarantees that he did not intend to establish a communist regime in the country. At the same time, he asked Stalin through Korneev 'to shield us from the pressure from the British', who were plotting with Mihailović to strip Serbia from the AVNOJ. Tito also asked for the Red Army to advance through Romania into south and central Serbia to participate with the Partisan divisions assisting in the liberation of Belgrade. In September, he reiterated the demand directly to Moscow, where at his own request he had flown to meet Stalin in secret. These measures, he argued, 'will resolve the issue of the Balkans'.96

\footnotetext{
${ }^{91}$ Edemskii, 'Moskva i Antifashistskoe Dvizhenie I. Broz Tito', 120 and From Korneev to Stalin, 1.8.1944, in RGASPI, f. 82, o. 2, d. 1371, II. 45-63.

92 M. Wheeler, 'Crowning the Revolution: the British, King Peter and the Path to Tito's Cave', in R. Langhorne (ed.) Diplomacy and Intelligence during the Second World War: Essays in Honour of F.H. Hinsley (Cambridge [Cambridgeshire]; New York 1985), 217.

${ }^{93}$ Soviet Policy in the Balkans. Memorandum by Secretary of State for Foreign Affairs, R9092, 7.6.1944, in NA, FO $371 / 43646$.

${ }^{94}$ From D/H170 to A/DH, 13.9.1944, in NA, HS 5/948 and D. Biber, 'Failure of a Mission: Robert McDowell in Yugoslavia, 1944', in G. C. Chalou (ed.) The Secrets war: the Office of Strategic Services in World War II (Washington, DC 1992), 194-217.

${ }_{95}^{9}$ Pis'mo Predsedatelia HKOli I. Broz Tito Narodnomu Komissaru Inostrannykh Del SSSR B.M. Molotovu, 5.7.1944, in Otnosheniia Rossii (SSSR) s lugoslaviei, 280-82.

${ }^{96}$ From Korneev to Stalin, 31.7.1944, in RGASPI, f. 82, o. 2, d. 1731, II. 7-12. Quoted also in Edemskii, 'Moskva i Antifashistskoe Dvizhenie I. Broz Tito', 116.
} 
Soviet troops entered Yugoslavia at the end of September under orders to fight the Germans and the 'reactionary forces of Yugoslavia of Nedić and Mihailović' ${ }^{97}$ The Soviets did not inform the Western Allies of Tito's request and only notified the British and US ambassadors that they had asked permission from the AVNOJ to temporarily cross the border to carry on operations against the Germans. In the way, they demonstrated that that they considered the committee to be the only legitimate power in the country and also avoided the creation of a precedent for the entrance of Western troops. ${ }^{98}$ The arrival of the Red Army was coupled with a peak in Soviet supplies reaching the AVNOJ, which was made possible by, among other things, the use of airfields in the Romanian territory and in Bari. ${ }^{99}$ At this point, Tito felt strong enough to fulfil the promise of creating a new government and summoned Šubašić to Yugoslavia. As with the agreement signed in June, this new pact reflected the balance of powers in the country: the king was to appoint a council of three regents proposed by the AVNOJ to represent him before a plebiscite could be held, and the regents were to put in place a new government which would be totally dominated by the AVNOJ. Tito was now the master of Yugoslavia.

The Yugoslav case suggests that, in the context of the shifting balance of forces amongst the Western Allies, Moscow was ready to put aside the popular front strategy and to encourage local communists to challenge the political order supported by the British and the Americans whilst the Second World War was still raging. The modification of Soviet policy in 1944 also has the potential retrospectively to shed light on the earlier period, highlighting that the disagreement with the Yugoslavs over the nature of the war in 1941-1943 never really brought into question the Soviets' recognition of the preeminent role played by Tito amongst the neighbour parties. The example of Yugoslavia, however, also shows that this apparently clear strategy covered deep uncertainties on the Soviet side as to the real

\footnotetext{
${ }^{97}$ Doklad Komanduiushchego Voiskami 3-go Ukrainskogo Fronta Nachal'niky General'nogo Shtaba Krasnoi Armii o Plane Belgradskoi Operatsii, 30.9.1944, in Russkii Arkhiv: Velikaia Otechestvennaia. Krasnaia Armiia v Stranakh Tsentral'noi, Severnoi Evropy. Dokumenty i Materialy. 1944-1945, 219-20.

${ }^{98}$ Both letters are published in Otnosheniia Rossii (SSSR) s lugoslaviei, 317-18 and quoted in Pavlowitch, Hitler's New Disorder, 234-35.

99 According to the data published by Sergienko, the Soviet division responsible to supply the partisan in Yugoslavia delivered between March and November 1944 over 961 tons of material, of which 150,36 in August, 224,7 in September and 261 in October. Svodnaia Itogovaia Tabliza Poletov Ekipazhei 5-I Gvardeiskoi Gomel'skoi Aviadivisi po Meziatsam, in Sergienko, Okazanie Sovetskim Soiuzom Voenno-Tekhnicheskoi i Kadrovoi Pomoshchi lugoslavii v Gody Vtoroi Mirovoi Voiny, 646.
} 
intentions of the British, the real space of manoeuvre enjoyed by Moscow and the way in which relations with a new communist state in the making should be established. It also shows that, trapped in the Marxist world-view which postulated the incompatibility of the socialist and capitalist worlds, Moscow was often unable to understand its opponents, looking for conspiracies where they did not exist.

In the short term Soviet policy appeared successful. By directing Tito to abandon his radical stance and adopt the slogan of national liberation, Moscow helped him to gain the confidence of the British, establishing the impression a collaboration between the Partisans and the King was indeed possible. Then the Soviets were able to support the communist takeover of the country without it affecting their relations with the Western Allies. Tito's flight to Moscow was a brutal awakening for Churchill, who only then realized that in Tito the British had 'nursed a viper'. ${ }^{100}$ The Soviets were also able convincingly to deny until the end the extent of their involvement with the Yugoslav communist movement, thus avoiding the risk that, if anything went wrong, the situation could be ascribed to them. In all this, they provided at the crucial moment the military, financial and diplomatic support that the Partisans needed to defeat their internal enemies and to gain credibility in the international area. Tito played his cards well, paying lip service to the Soviets when needed and continuing to advance his cause step by step whilst maintaining their support.

The seeds for further conflicts, however, had been planted. Paradoxically, by pushing Tito to widen his popular base in Yugoslavia after 1942, the Soviets had established him as the leader of a communist state that was now challenging Moscow's supremacy. Created by Stalin and nursed by Churchill, 'the viper' Tito was now ready to bite eastward. Exacerbated by Tito's attempt to impose his leadership on the other 'popular democracies' in the Balkans after the war, the conflict between the two leaders of the communist movements eventually became unmanageable, and in 1948 led to the most serious split in the communist world.

${ }^{100}$ From Churchill to Eden, 19.12.1944, in NA, CAB 120/729. 